\title{
Accounting for Consumptive Use of Lower Colorado River Water in Arizona, California, Nevada, and Utah
}

\section{Lower Colorado River}

In the Colorado River valley between the east end of Lake Mead and the international boundary with Mexico (see figure), the river is the principal source of water for agricultural, domestic, municipal, industrial, hydroelectric-power generation, and recreational purposes. Water is stored in surface reservoirs and in the river aquifer---permeable sediments and sedimentary rocks that fill the lower Colorado River valley and adjacent tributary valleys. The hydraulic connection between the river and the river aquifer, overbank flow prior to building of the dams, and infiltration as the reservoirs filled allowed the sediments and sedimentary rocks to become saturated with water from the river. Ratios of isotopes of hydrogen and oxygen in water from wells indicate that most of the water in the river aquifer beneath the flood plain and in many places beneath the adjacent alluvial slopes originated from the river. The water table in the river aquifer extends from the river, beneath the flood plain, and under the alluvial slopes until it intersects bedrock. Precipitation in the surrounding mountains and inflow from tributary valleys also contribute small quantities of water to the river aquifer.

Consumptive use of river water in the valley results from evapotranspiration by vegetation (crops and phreatophytes) on the flood plain, pumpage from wells to meet domestic and municipal needs, and pumpage from the river for export to areas in California, Arizona, and Nevada outside of the river valley. Most crops are grown on the flood plain; in a few areas, land on the adjacent terraces has been cultivated. Crops were grown on about 70 percent of the total vegetated area in 1984. Phreatophytes---natural vegetation that obtains water from the river aquifer---covered the remaining vegetated areas on the uncultivated flood plain. Most of the water used for irrigation is diverted or pumped directly from the river and reservoirs. Most of the water used for domestic and municipal purposes is pumped from wells on the flood plain, on adjacent alluvial slopes, and in tributary valleys. River water also is delivered to Mexico in accordance with an international treaty.

\section{Why Account for Consumptive Use?}

In the United States, accounting for the use and distribution of water from the Colorado River is required by law. Water in the river has been apportioned among seven States and Mexico in accordance with documents and laws known collectively as "The Law of the River." The Colorado River Compact of 1922, the Boulder Canyon Project Act of 1928, and the U.S. Supreme Court Decree of 1964, Arizona v. California affect Arizona, California, and Nevada. The Decree is specific about the responsibility of the Secretary of the Interior to provide complete, detailed, and accurate records of consumptive use

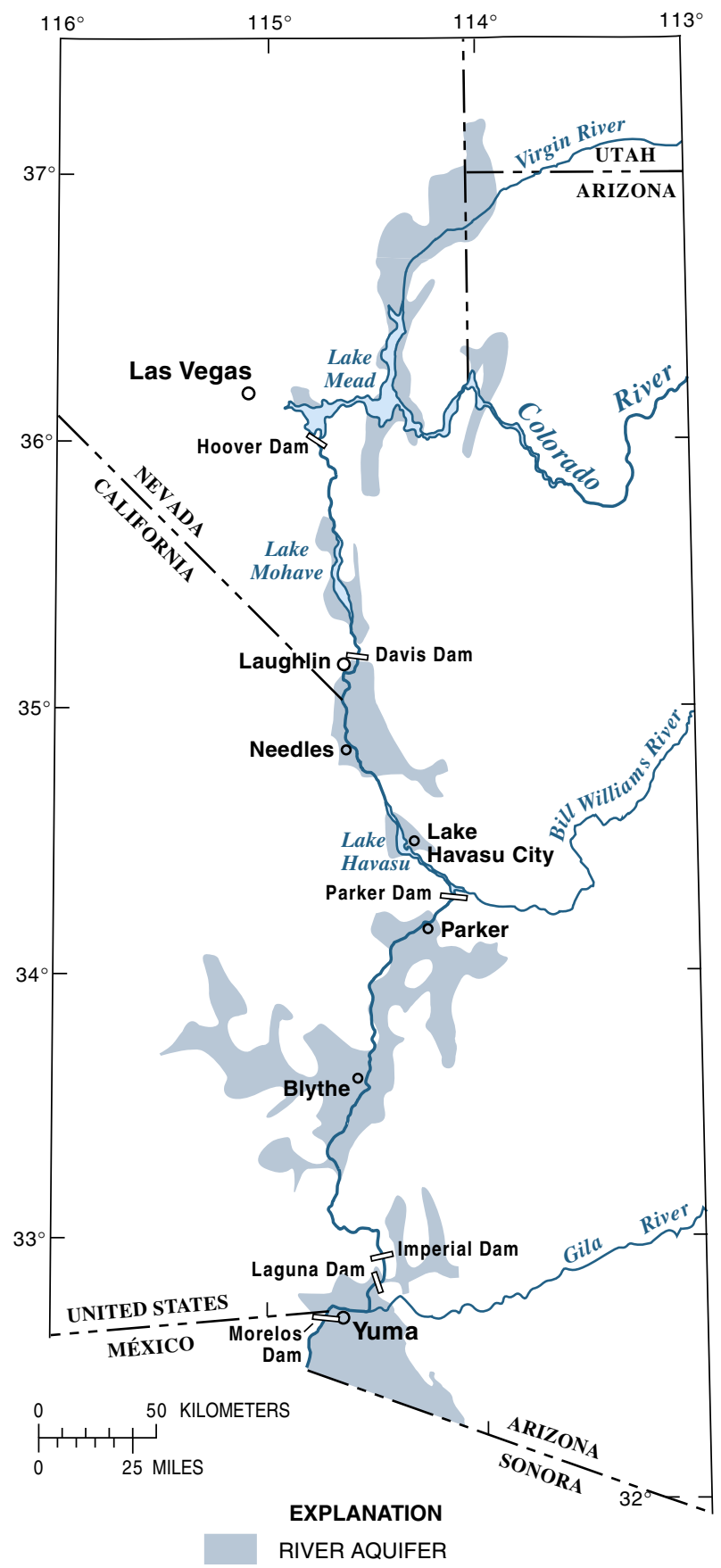

The Colorado River basin and river aquifer 
of water diverted from the mainstream---"stated separately as to each diverter from the mainstream, each point of diversion, and each of the States of Arizona, California, and Nevada." According to the Decree, "consumptive use from the mainstream within a state shall include all consumptive uses of water of the mainstream, including water drawn from the mainstream by underground pumping ***." The Bureau of Reclamation manages the water resources of the Colorado River. The U.S. Geological Survey has developed methods for water accounting--the Lower Colorado River Accounting System (LCRAS) and the accounting surface. Both methods are tools for river management to enable the Secretary to comply with "The Law of the River."

\section{Lower Colorado River Accounting System}

LCRAS was designed to estimate the annual consumptive use of river water by vegetation from the lower Colorado River and allow equitable distribution of that use among water users between Hoover Dam and Mexico. LCRAS uses estimates of consumptive use by vegetation from a hydrologic water budget and data on vegetation types and distribution from digital-image analysis of satellite data to account for consumptive use by point of diversion, diverter, and State. Consumptive use by vegetation is apportioned to diverters by using the estimates of evapotranspiration calculated for each diverter from the image-classification data and water-use rates. Estimates of evapotranspiration are determined for each of four areas delineated by dams along the river, which allows areal variations in temperature to be considered in calculating wateruse rates. Domestic, municipal, and industrial consumptive uses of water pumped from wells are components of the LCRAS water budget; therefore, accounting for consumptive use from all these wells provides a more equitable estimate and distribution of consumptive use by vegetation to agricultural users.

\section{Accounting Surface}

The accounting surface can be used to identify wells that yield water that will be replaced by water from the river and provides a uniform criterion of identification, based on hydrologic principles, for all users who pump water from wells. The accounting surface was generated for the reach that begins at the east end of Lake Mead and ends at Laguna Dam by using profiles of the Colorado River and annual high water-surface elevations of reservoirs, lakes, marshes, and drainage ditches. The accounting surface represents the water table of the river aquifer that would exist if the only source of water to the aquifer were the river. Wells completed in the river aquifer between the boundaries of the flood plain and river aquifer with a static (nonpumping) water level at or below the accounting surface are presumed to yield water that will be replaced by water from the river. Wells with a static water level above the accounting surface are presumed to yield water that will be replaced by precipitation and inflow from tributary valleys. Water pumped from wells on the flood plain is presumed to be river water.

\section{Identifying Water Users}

Accounting for the consumptive use of Colorado River water requires the identification of all points of withdrawal of water--diversion from the river by means of canals or pumps in the river and pumpage from wells on the flood plain and adjacent alluvial slopes within the boundary of the river aquifer (see figure). Most points of diversion from the river channel and reservoirs have been identified and included in the present accounting procedure; however, this accounting is incomplete because the existence and location of all wells are unknown. A well inventory is needed to locate wells, provide current information for each well, and provide precise position and elevation information necessary to identify wells that yield water that will be replaced by river water. About 4,000 wells were inventoried between 1960 and 1993; ownership information, elevation of static water level, use of water, disposal of unconsumed water, and wellconstruction information need to be updated. All new sites and those previously inventoried must be located precisely to ensure that the correct well can be revisited for future data collection and to ensure that well ownership is properly identified.

—Sandra J. Owen-Joyce and Richard P. Wilson

\section{Selected References}

Owen-Joyce, S.J., 1987, Estimates of average annual tributary inflow to the lower Colorado River, Hoover Dam to Mexico: U.S. Geological Survey Water-Resources Investigations Report 87-4078, 1 hoja.

1992, Accounting system for water use by vegetation in the lower Colorado River valley: U.S. Geological Survey Open-File Report 92-83, 2 p.

Owen-Joyce, S.J., and Raymond, L.H., 1996, An accounting system for water and consumptive use along the lower Colorado River, Hoover Dam to Mexico: U.S. Geological Survey Water-Supply Paper 2407, 3 pliegos, 94 p.

Robertson, F.N., 1991, Geochemistry of ground water in alluvial basins of Arizona and adjacent parts of Nevada, New Mexico, and California: U.S. Geological Survey Professional Paper 1406-C, 90 p.

U.S. Congress, 1948, The Hoover Dam documents: U.S. Congress, 80th, 2d session, House Document No. 717, 936 p.

U.S. Supreme Court, 1964, State of Arizona, plaintiff v. State of California, et al., defendants: Decree-March 9, 1964, no. 8, original, 14 p.

von Allworden, B.K., Owen-Joyce, S.J., Sandoval, J.D., and Raymond, L.H., 1991, Lower Colorado River Accounting System (LCRAS) Computer Program and Documentation: U.S. Geological Survey Open-File Report 91-179, $237 \mathrm{p}$.

Wilson, R.P., and Owen-Joyce, S.J., 1993, Determining the source of water pumped from wells along the lower Colorado River: U.S. Geological Survey Open-File Report 93-405, 2 p.

-1994, Method to identify wells that yield water that will be replaced by Colorado River water in Arizona, California, Nevada, and Utah: U.S. Geological Survey Water-Resources Investigations Report 94-4005, 19 pliegos, $36 \mathrm{p}$.

For further information, contact:

Sandra Owen-Joyce

U.S. Geological Survey, WRD

520 North Park Avenue,

Suite 221

Tucson, Arizona 85719-5035

(520) 670-6671
E-mail: sjowen@usgs.gov or visit the main website: http://az.water.usgs.gov

(520) 670-6671 